\title{
Towards a Common European Asylum System: Asylum, Human Rights, and European Values
}

\author{
HAROLd SHEPHERd
}

\begin{abstract}
The turn of the millennium has been met with a considerable amount of work in the area of refugee protection, culminating in the UNHCR's Agenda for Protection and Convention Plus initiatives. In addition, in 1999 the European Union embarked on a five-year program to develop a Common European Asylum System as mandated by the Treaty of Amsterdam. Work done by the European Commission sought to incorporate asylum into broader issues of immigration, border security, and foreign relations. As a result, entitlements were generally limited to those that have been mandated by applicable international, European, or domestic law. Some exceptions were further reduced at the political level. Functional values of bureaucratic efficiency and pragmatic political considerations converged to create the lowest common denominator. On the other hand, voices in civil society were raised to protest this approach, advocating that normative values that underpin international human rights law should serve as the interpretative context. In light of this debate, this may be an appropriate time for the international community to revisit the question of status for those not described in the Geneva Convention.
\end{abstract}

\section{Résumé}

Le tournant du millénaire a vu beaucoup de travail accompli dans le domaine de la protection des droits des réfugiés, débouchant sur les initiatives de l'UNHCR, Agenda pour la protection et Convention Plus. En plus, en 1999, l'Union Européenne a lancé un programme étalé sur cinq ans et visant à développer un système européen commun sur le droit d'asile comme mandaté par le Traité d'Amsterdam. Le travail déjà accompli par la Commission Européenne visait à inscrire le droit d'asile dans les questions plus larges de l'immigration, de la sécurité aux frontières et des relations extérieures. Par conséquent, les critères d'admissibilité furent généralement limités à ceux déjà mandatés par les lois internationales, européennes ou domestiques applicables. Certaines exceptions subirent une réduction supplémentaire quand ils arrivèrent au niveau politique. Les valeurs fonctionnelles de l'efficacité bureaucratique se sont donc alliées à des considérations politiques pragmatiques pour produire le plus petit dénominateur commun. D'autre part, des voix se sont élevées dans la société civile pour protester contre cette approche, arguant que les normes qui sous-tendent le droit international en matière de droits de la personne devraient servir de cadre interprétatif. À la lumière de ces débats, il se peut que ce soit le moment opportun pour la communauté internationale de revoir le statut de ceux qui ne sont pas décrits dans la Convention de Genève.

$\mathrm{E}$ urope is now in the process of trying to reinvent itself in an era of globalization as an interdependent community of shared values, markets, labour, and capital. In order to achieve this goal, the European Union has set about the task of creating an area of freedom, security, and justice with open internal borders. The result of advances made in this area has led to the phenomenon of secondary 
migration within Europe. Pull factors relating to reception conditions, asylum determination procedures, and interpretation of refugee law, in addition to such other factors as language and colonial ties, led to a perceived disparity among States with respect to assuming responsibilities towards asylum seekers. Concern about "burden sharing" and "asylum shopping" led to discussions about how best to address what was perceived to be a problem. Rules governing State responsibility for deciding asylum claim and plans for a European Refugee Fund were developed. In order to decrease the incentive to make asylum claims in Europe elsewhere than the country of admission and in order to promote consistency, a comprehensive program for a Common European Asylum System has been proposed, with implementation of minimum standards by May of 2004 . This project requires the balances of competing interests those of the individual rights of asylum seekers with those of the community at large. The degree to which both have been accommodated in a way that is both consistent with international human rights principles and with responsible use of finite resources is a matter of debate, as will be evident in the following analysis.

\section{Legal Framework}

The European Union [the EU] was established on November 1, 1993, by the Treaty of the European Union ${ }^{1}$ that was signed at Maastricht on February 7, 1992 [the Maastricht Treaty]. It includes as one of its objectives the free movement of persons. As a corollary to this principle, asylum policy was made an issue of common interest as part of co-operation in the areas of justice and home affairs under Article K.1 of Title VI. As part of the "third pillar" of the EU, asylum policy was a matter of intergovernmental agreement. A significant development took place when the Treaty Establishing the European Community ${ }^{2}$ was amended by the Treaty of Amsterdam amending the Treaty of the European Union, the Treaties Establishing the European Communities and Certain related Acts, signed on October 2, 1997, and entered into force on May 1, 1999 [the Treaty of Amsterdam ]. ${ }^{3}$ In particular, the Treaty of Amsterdam moved asylum from the third pillar of intergovernmental co-operation as a matter of justice and home affairs to the first pillar of community law. Article 63 of the amended Treaty Establishing the European Community ${ }^{4}$ [the TEC] allowed five years to implement a common asylum policy that would be binding on Member States. Article 67 provides that during the five-year transitional period implementation is to be done by unanimous vote of the Council based on a proposal from either the European Commission or a Member State after consultation with the European Parliament. After five years, Members States lose their right to bring proposals directly to the
Council. Instead, a proposal must be made to the European Commission which then considers whether to submit it to the Council. Except in designated areas such as visa policy, the Council shall act on the Commission's proposals. This strengthens the Commission's hand considerably after May of 2004.

In the matter of asylum, Article 63 requires that common standards be implemented with respect to state responsibility for considering asylum applications, minimum reception standards, minimum qualification standards, and minimum procedural standards for granting or withdrawing refugee status. With respect to refugees and displaced persons (which are not subject to the five-year implementation requirement), it mandates minimum standards for temporary protection and mechanisms to promote responsibility sharing among Member States.

The European Council met at Tampere from October 15 to 16,1999 , to establish measures to implement Article 63 by means of a Common European Asylum System. The decision was made to achieve this goal in two phases. In the short term, common standards would be developed for implementation by each respective national asylum determination system (sometimes referred to as "Tampere I"). In compliance with the five-year requirement imposed by Article 63, these provisions must be implemented by May of 2004. The long-term plan is to create a common asylum procedure and a uniform European Union refugee status (Tampere II).

In addition to policy support from the Immigration and Asylum Committee of Justice and Home Affairs, an governmental asylum consultation group has been created to act as a forum to promote consistency in asylum determinations within Europe. After the dissolution of CIREA (Centre for Information, Reflection and Exchange on Asylum) in June of 2002, the European Union Network for Asylum Practitioners (EURASIL) was created. Representatives from national asylum-determination authorities meet six to eight times per year with invited international partners to exchange information and experiences in deciding asylum claims.

\section{Responsibility Sharing and the Dublin Convention}

The Schengen Convention implementing the Schengen Agreement of 14 June 1985 between the Governments of the States of the Benelux Economic Union, the Federal Republic of Germany and the French Republic on the gradual abolition of checks at their common borders ${ }^{5}$ was signed on June 19, 1990 [the Schengen acquis]. However, it did not come into force until 1995 with ratification by ten States. This was later expanded to thirteen EU Member States in addition to 
Norway and Iceland. Ireland and the United Kingdom declined to ratify or accede to this Convention. It provides for free movement among states with a common external border (subject to the temporary imposition of border controls for reasons of public order, as France has done to combat the entry of drugs from the Netherlands and Belgium).

The Schengen acquis was integrated into the European Union by means of the Treaty of Amsterdam on May 1, 1999 , through a protocol. On May 18, 1999, Norway, Iceland, and the European Union entered into an agreement to permit these two non-EU countries to continue to participate. In order to operationalize a common external border, the Schengen Information System (SIS) was established in 1995 and is now used by thirteen EU states, plus Norway and Iceland. The next generation, SIS II, is being developed to add new features such as biometric identification data and new categories of persons of interest. In addition, it will allow the United Kingdom, Ireland, and the ten accession states to participate in the system. Another database known as the Visa Information System (VIS) is also being developed to store personal information from visa applications to EU member states.

In response to the creation of an area of free movement within Europe, the resulting issue of "asylum shopping" was dealt with by the Convention Determining the State Responsible For Examining Applications For Asylum Lodged In One of the Member States of the European Communities, ${ }^{6}$ signed on June 15, 1990, that came into force on September 1, 1997 [the Dublin Convention]. All EU Member States became parties to this Convention that determines state responsibility for determining asylum claims. To avoid the situation in which a failed asylum seeker files another claim in a second jurisdiction, the Convention provides for a regime in which only one determination is made under the responsibility of a State identified by established criteria. Given that the Dublin Convention is an instrument of public international law, a Council regulation was required to replace it with Community law in accordance with Article 63(1)(a) of the amended Treaty of the European Community. The document, entitled Council Regulation establishing the criteria and mechanisms for determining the Members State responsible for examining an asylum application lodged in one of the Members States by a third country national, ${ }^{7}$ is sometimes referred to as "Dublin II." In order to keep track of claimants for purposes of Dublin II, "Eurodac" was created by Council Regulation (EC) No. $2725 / 2000$ of December $11,2000,{ }^{8}$ to permit exchange of fingerprints of asylum seekers among Member States. In addition to this responsibility-sharing regime, a European Refugee Fund was established by Council Decision on September 28, $2000^{9}$ pursuant to Article 63(2)(b) of the Treaty of the European Community, as amended by the Treaty of Amsterdam.

\section{Temporary Protection}

In accordance with Articles 63(2)(a) and (b) of the TEC, the Council enacted the Council Directive on minimum standards for giving temporary protection in the event of a mass influx of displace persons and on measures promoting a balance of efforts between Members States in receiving such persons and bearing the consequences thereof ${ }^{10}$ [the Temporary Protection Directive]. In addition to those who meet the definition of a Convention refugee in accordance with Article 1A of the 1951 Geneva Convention, this directive also applies to those who have been displaced by armed conflict, endemic violence, or "persons at serious risk of, or who have been the victims of, systematic or generalised violations of their human rights." Temporary protection is without prejudice to the person applying to be recognized as a Convention refugee. In response to a proposal by the European Commission, a Council decision is adopted by qualified majority to make a designation for purposes of temporary protection. Unless otherwise terminated, temporary protection lasts for one year and may be extended by the Council by qualified majority to extend it up to one year. The effect of the Council decision is to grant temporary protection throughout the European Union to displaced persons who are members of the specified group. Obligations incumbent on Member States include the issuance of residence permits, necessary visas, access to suitable accommodation, social welfare, medical care, employment authorization, educational opportunities, and vocational training (subject to priority given to EU citizens or other designated persons). Article 17 provides that those who enjoy temporary protection have the right to apply for asylum at any time.

\section{Minimum Reception Standards}

In accordance with subparagraph 1(b) of Article 63 of the TEC, Council Directive 2003/9/EC of 27 January 2003 laying down minimum standards for the reception of asylum seekers ${ }^{11}$ [the Reception Directive] was enacted by the Council, establishing minimum standards for the reception of asylum seekers based on a proposal from the European Commission after consultation with the European Parliament, the Economic and Social Committee, and the Committee of the Regions. The preamble identifies one goal of the Reception Directive as being to ensure that asylum seekers have a dignified standard of living and comparable living conditions throughout the EU. In addition, it is hoped that harmonization of reception conditions would reduce secondary movement. The Directive only applies to those who make asylum claims under the 1951 Geneva Convention, not those 
who seek other forms of subsidiary protection, including temporary protection under the Temporary Protection Directive.

The Reception Directive provides for the provision of information concerning benefits and communication of obligations respecting reception conditions. Information must be given about organizations that provide assistance, be it legal, medical, or other, that is relevant to reception conditions. A status document as an asylum seeker must be issued within three days of receipt of the application. A travel document must be issued if serious humanitarian reasons require the person's presence in another State. Although freedom of movement is protected, States are permitted to restrict movement to a prescribed area provided that this does not interfere with private life or access to benefits under the Reception Directive. Detention is authorized for reasons of public order. Member States must make best efforts to respect the principle of family unity. Medical screening is permitted on public health grounds. Minors must have access to the education system on the same basis as nationals within three months of the asylum claim having been made (or up to one year for training designed to facilitate access to the educational system). Member States have discretion to determine a waiting period before an asylum seeker can access the labour market. However, if after one year the application has not been decided through no fault of the person concerned, the State shall determine conditions for access to the labour market. Priority can be given to EU nationals and other designated persons. Employment authorization may not be revoked if an appeal of a negative decision has a suspensive effect. The Reception Directive then outlines material reception conditions. Provisions are also made for those with special needs.

\section{Minimum Procedural Standards}

A draft Council Directive on minimum standards on procedures in Member States for granting and withdrawing refugee status [the Procedural Directive] was adopted by the European Commission on September 20, 2000..$^{12}$ After consultation with the Council, the European Parliament, and the Economic and Social Committee, it was amended through document /COMM/2002/0326 final-CNS 2000/0238, ${ }^{13}$ but has not yet been enacted. The draft Procedural Directive applies to applications for asylum, defined in Article 2 as referring to requests for international protection under the Geneva Convention, not to other forms of subsidiary protection. Accelerated procedures are permitted in a number of cases, including applications that have been found to be inadmissible, manifestly unfounded, repeat claims, port of entry applications, or cases in which there is evidence of misrepresentation or abuse (including destroying identity documents in cases where identity is uncertain or making an asylum application with unreasonable delay in circumstances in which it appears that the claim has been made to delay removal). Reasonable time limits are established for processing, but claims cannot be rejected simply because they were not made at the first opportunity. Border officials must be properly trained. Applicants must be informed about procedure and right to counsel, and must be provided with the services of an interpreter. Decisions must be made individually by qualified personnel. With certain exceptions, applicants have the right to a personal interview from which a transcript is prepared. The benefit of the doubt is to be given to the claimant provided that a genuine effort has been made to substantiate the claim, all available evidence has been obtained and verified, and the examiner is satisfied that the statements are "coherent and plausible and do run counter to generally known facts relevant to his/her case" (Art. 16). States are required to provide an effective remedy before a court of competent jurisdiction against a negative decision that must be provided in writing and include reasons. Provisions are also made for procedures relating to unaccompanied minors and to the detention of asylum seekers.

This proposed Procedural Directive reflects a common practice in Europe of dividing responsibilities between the Interior Ministry that determines admissibility of the application and an administrative tribunal that assesses its substance. In many countries, the preliminary examination by the Interior Ministry can reject the application on the basis that it is manifestly unfounded without referring it to the tribunal responsible for refugee status determination. Article 29 limits such cases to situations in which the officer determines that there is no nexus between the stated risk and Article 1(A) of the Geneva Refugee Convention, the applicant is from a safe country of origin as defined in the Procedural Directive, or a prima facie case can be made for exclusion under the Geneva Convention.

Article 25 of the draft Procedural Directive permits Member States to reject an application for asylum in five cases: (a) a Member State, Norway, or Iceland has acknowledged responsibility for examining the application; (b) the applicant arrived in the EU from a "first country of asylum" in accordance with Article 26 (the person has been granted asylum in a third country and can still avail him or herself of its protection); (c) the applicant arrived from a "safe third country" as defined in Article 27 and in accordance with the principles set out in Article 28 and Annex I; (d) extradition by a Member State or a "Safe Third Country," and (e) indictment by an International Criminal Court.

On October 2, 2003, the Council considered the issue of safe countries of origin and safe third countries, and on November 6, 2003, it looked at several issues relating to the 
designation of safe third countries. A revised draft of the Directive was issued on December 4, 2003, as ASILE 66 (15198/03) with proposals from Member States found in ASILE 66 ADD 1. Under the Irish Presidency, an informal meeting of the Justice and Home Affairs Ministers was held in Dublin on January 22 and 23, 2004. ${ }^{14}$ Two issues of particular importance were identified at the meeting. The first concerns the degree to which the application of the safe-third-country provision should be dependent on a past connection to the country and the possibility of seeking and obtaining asylum in that country. The second concerns a proposal in amended Article 28A that provides for "neighbouring safe third countries." If the applicant comes from a country that, by national legislation, offers the protection of both the 1951 Geneva Convention and the 1950 European Convention for the Protection of Human Rights and Fundamental Freedoms [the European Convention on Human Rights or the ECHR], the Member State may refuse access to its asylum determination system. After EU enlargement on May 1, 2004, this would apply to the nineteen non-EU members of the Council of Europe that have ratified the ECHR. The Dublin meeting raised the questions of whether Article 28A should maintain ratification of the ECHR as a requirement and whether the Directive should include a common EU list of safe third countries as a requirement for the application of Article 28A. An example of NGO rejection of the notion of what it refers to as "super safe third neighbouring counties" can be found in the submissions to the Dublin meeting made by the European Council on Refugees and Exiles which advocates individual examination of every claim. ${ }^{15}$

\section{The Proposed Qualification Directive}

In accordance with Article 63 of the TEC, paragraph 38((b) (i and ii) of the Vienna Action Plan, Conclusion 14 of the Tampere European Council and with reference to the "scoreboard" presented to the Council and the European Parliament in March of 2000, the European Commission published a Proposal for a Council Directive on minimum standards for the qualification and status of third country nationals and stateless persons as refugees or as persons who otherwise need international protection, ${ }^{16}$ [the Qualification Directive]. The Directive took the March 4, 1996, Joint Position of the Council concerning the harmonized application of the definition of a Convention refugee as a starting point, but significantly amends it, then goes on to consider subsidiary protection outside the purview of the Geneva Convention.

Consultation was mandatory for the European Parliament, but optional for the Committee of the Regions and the Economic and Social Committee. The Committee of the Regions reported back on May 16, 2002. ${ }^{17}$ It acknowledges that those who qualify for refugee status under the Geneva Convention are entitled to the same access to services and opportunities as nationals. However, those granted subsidiary protection may have different entitlements, for example, with respect to access to the labour market.

The Economic and Social Committee reported on May $29,2002,{ }^{18}$ pointing out that the priority rule according to which an application must first be assessed under the Geneva Convention before subsidiary protection is considered must be respected in order not to weaken this Convention. With respect to status, the Committee criticizes the distinction made between refugee status that results in a five-year residency permit and subsidiary protection that only entitles one to a one-year permit, stating that there is no reason why one should be shorter than the other. In addition, the Committee is of the opinion that those who have been granted subsidiary protection should have the right to work as soon as their need for protection has been recognized.

Some problematic aspects to the proposed Qualification Directive include the following.

1. Article 8 provides that sur place claims may be based on activities done after leaving one's country of origin "save where it is established that such activities were engaged in for the sole purpose of creating the necessary conditions for making an application for international protection." This exception has elicited the criticism that this is inconsistent with the terms of the Geneva Convention that do not exclude persons in this category from its protection.

2. The proposed Directive refers to applications for international protection. The UNHCR is of the view that this term is properly used to describe protection provided by international agencies such as the UNHCR, not domestic protection that is more properly referred to as asylum. ${ }^{19}$

3. Article 5 defines subsidiary protection as being based on a "well-founded fear of suffering serious and unjustified harm as described in Article 15." Article 15 outlines three categories of subsidiary protection: (a) torture or inhuman or degrading treatment or punishment, (b) violation of a human right, sufficiently severe to engage the Member State's international obligations, or (c) a threat to his or her life, safety or freedom as a result of indiscriminate violence arising in situations of armed conflict, or as a result of systematic or generalised violations of their human rights. It has been pointed out that some human rights standards are non-derogable expressions of jus cogens. For example, it is inappropriate to ask whether torture can be justified. Professor Guy Goodwin-Gill has pointed out that the use of the term "unjustified" risks being interpreted as a separate test to be applied within a legal analysis. ${ }^{20}$ 
4. Article 5 provides that "international protection" may be granted to a third-country national. That is to say, the proposed Qualification Directive only applies to applications made by those who are not European Union citizens. This is consistent with the Protocol to the Treaty of Amsterdam that also establishes this principle. The criticism has been made that the right to make an asylum claim under the Geneva Convention in another contracting State is undermined by this provision. There may well be some legitimate protection needs within the meaning of the Convention notwithstanding the fact that the State in question is a member of the EU.

5. Article 21 provides that those recognized to be Convention refugees and accompanying family members are entitled to a residence permit valid for a minimum of five years, renewable automatically. Those granted subsidiary protection and their accompanying family members are only entitled to a residence permit that is valid for one year, automatically renewed for a period of at least one year until authorities establish that protection is not longer needed. This has been widely criticized by NGOs as having no rational basis, given that there is no appreciable difference between refugee and subsidiary protection with respect to how long it will be required and the settlement needs of the protected person. This was also recognized by the Economic and Social Committee, as previously noted.

6. Article 24(1) requires that those who have been granted refugee status be permitted to work immediately upon recognition. Article 24(3) permits States to delay entry into the labour market for up to six months in cases of those granted subsidiary protection. However, Articles 25,26 , and 27 of the proposed Directive do not distinguish between refugee and subsidiary status with respect to access to education, social welfare, or health and psychological care.

7. There has been some debate about whether the proposed Qualification Directive excludes Palestinians from its applicability when they make asylum claims in Europe. The reason for this is that Article 1D of the Geneva Convention is an exclusion provision that concerns those who are in receipt of protection from United Nations agencies other than the UNHCR. Because Palestinians receive assistance from the United Nations Relief and Works Agency (UNRWA), the Geneva Convention is not applicable to their situation. However, Article 1D goes on to say that the Geneva Convention applies when such protection or assistance ceases for any reason. The proposed Qualification Directive, at Article 14(1)(a), excludes from refugee status any applicant "who is at present receiving protection or assistance from organs or agencies of the United Nations other than the United Nations High Commissioner for
Refugees." This could be interpreted to mean that Palestinians who arrive in Europe to make an asylum claim are excluded from the protection of the Geneva Convention and must return to seek protection from UNRWA. However, Professor Goodwin-Gill has pointed out that, under the Geneva Convention, UNRWA protection ceases when a person leaves its jurisdiction. As a result, the second paragraph of Article 1D applies and protection may be granted under the Geneva Convention in Europe. To remove the ambiguity of the text on this point, Professor Goodwin-Gill suggests that Article 2(c) of the Qualification Directive be amended to include in the definition of a refugee those to whom the second paragraph of Article 1(D) of the Geneva Convention applies. ${ }^{21}$

On the other hand, the Qualification Directive has proposed to resolve the debate concerning agents of persecution and membership in a particular social group. Article 11(2)(a) states that it is "immaterial whether the persecution stems from the State, parties or organisations controlling the State, or non-State actors where the State is unable or unwilling to provide effective protection." This raises the bar for countries that require that a non-State agent of persecution act with the consent or acquiescence of the State to be considered persecution under the Geneva Convention. Article 11(2) goes on to specify in (b) that it does not matter whether a political opinion is actually held, only that the agent of persecution attributes the belief to the applicant. Article 11(2)(c) states that "it is immaterial whether the applicant comes from a country in which many or all persons face the risk of generalised oppression." Article 12(d) specifies that the concept of a social group includes:

certain fundamental characteristics, such as sexual orientation, age or gender, as well as groups comprised of persons who share a common background or characteristic that is so fundamental to identity or conscience that those persons should not be forced to renounce their membership. The concept shall also include groups of individuals who are treated as "inferior" in the eyes of the law.

These provisions are a welcome development that harmonize conflicting European approaches and follow interpretations adopted by many national asylum-determination systems that use the ejusdem generis principle to extrapolate human rights and anti-discrimination categories from the other grounds enumerated in the Geneva Convention. ${ }^{22}$

\section{Council Directive on the Right to Family Reunification}

The major difference between the Council Directive on the Right to Family Reunification ${ }^{23}$ [the Family Reunification 
Directive] as implemented in 2003 and the original proposal made by the European Commission on January 11, 2000, ${ }^{24}$ is that the draft version applied to both refugee and subsidiary protection. The Directive as implemented is restricted to those who have been determined to be Convention refugees. This is a significant step backwards with respect to the status that attaches to subsidiary protection. Neither version extended its scope to those admitted on the basis of temporary protection. The Family Reunification Directive authorizes entry to a spouse and to unmarried minor children of a Convention refugee, with the exception that those twelve years of age and older who arrive independently may be subject to statutory integration criteria. Entry may be authorized for the parents of the refugee or his or her spouse in cases in which they are dependent on the refugee and do not enjoy proper family support in the country of origin. Unmarried adult children may also be authorized to enter if they cannot provide for their own needs for health reasons. Provision is also made for common-law spouses. Article $10(2)$ is proper to refugees and permits family reunification of other family members not referred to in Article 4 if they are dependents of the refugee. Special provisions are made for unaccompanied minors to bring parents into the country in Article 10(3). If the application is made within three months of obtaining refugee status, the settlement criteria of Article 7 do not apply. Family members are entitled to have access to education, employment, and training. However, Member States may set conditions or delay in authorizing employment for up to twelve months.

\section{Agenda for Protection and Convention Plus Initiatives}

The global consultations that began in December 2000 to mark the fiftieth anniversary of the 1951 Geneva Convention led to the approval of an "Agenda for Protection" by the 2002 Executive Committee of the UNHCR. Among the six goals established are strengthening the implementation of the Convention, the protection of refugees within broader migratory movements, sharing burdens and responsibilities more equitably, building capacities to receive refugees, redoubling the search for durable solutions, and addressing security concerns. The UNHCR challenged the international community to respond to this initiative by developing programs and policies that implement a comprehensive response to asylum-related migration flows known as "Convention Plus."

The European Commission drafted a report on implementation of the Agenda for Protection, published at Brussels on March 26, 2003, as $\operatorname{COM(2003)~} 152$ final entitled Communication from the Commission to the Council and the European Parliament on the common asylum policy and the
Agenda for Protection. This document incorporates work done in the area of the Common European Asylum System with broader issues of racism, combating the trafficking in human beings, domestic security issues, external border controls, managing illegal migratory flows, and stronger dialogue and partnership with third countries. An important issue studied was the question of external processing of refugee claims through protected entry procedures and resettlement programs. At present, five of fifteen EU countries have formal procedures for processing refugee claims outside the country and granting admission. Six others have informal procedures on a case-by-case basis. The Commission recommends that the EU consider a common European approach to protected entry procedure and resettlement that works in conjunction with partnership with third countries in developing protection capacity in the countries of first asylum and supporting other durable solutions in the form of local integration or voluntary return. As part of this process, the EU made the negotiation of readmission agreements part of broader negotiations on such issues as better market access, preferential trade tariffs, visa policies, quotas for migrant workers, development aid, and the like. ${ }^{25}$ As part of the Agenda for Protection, the Commission considered elements of the Common European Asylum System to advocate for a system that is fairer, faster, and more efficient, particularly with respect to the removal of failed asylum seekers. A second important report on this issue was published by the Commission on June 3, 2003, as COM (2003) 315 final-Communication from the Commission to the Council and the European Parliament: Towards more accessible, equitable and managed asylum systems. The Communication proposes a model that includes use of closed reception facilities for up to one month in conjunction with rapid determination of claims and removal. Mention is made of a "growing malaise in public opinion" in response to abuse of asylum procedures, mixed migratory flows, smuggling practices, and use of asylum procedures to improve living conditions unrelated to protection needs. Asylum policy is set squarely within the parameters of "orderly and managed arrival," responsibility sharing, both within the EU and with regions of origin, and efficient and enforceable asylum decision making and return procedures. At page 13, the Communication cites the discouraging of abuse of the asylum system as another important objective. In 2002, the Council adopted three action plans designed to combat illegal immigration and trafficking in human beings, to strengthen external border controls, and to facilitate removal of third-country nationals.

The focus of the Commission has been on creating a seamless web of asylum, immigration, and foreign policy that begins with the root causes of forced migration, follows 
on to solidarity and capacity building with countries of first asylum, considers questions related to durable solutions (including protected entry procedures and resettlement programs), and then proceeds to address issues of appropriate reception standards, fast and fair asylum determination procedures, the expeditious removal of failed claimants in conjunction with the negotiation of readmission agreements, and, finally, voluntary return programs when changes in country conditions warrant it.

\section{Commentary}

The nascent Common European Asylum System is emerging within the context of a debate between two fundamentally different approaches to protection. A good example of this can be seen with respect to subsidiary protection. From the point of view of consistency in application of international human rights principles, there should be no difference with respect to procedures, substantive status, duration of protection, and family reunification. This perspective has not only been advocated by many voices in civil society, ${ }^{26}$ but also by the Economic and Social Committee. It is rooted in international human rights values that are reflected in what is often referred to as the International Bill of Rights the 1948 Universal Declaration of Human Rights, ${ }^{27}$ the International Covenant on Civil and Political Rights, ${ }^{28}$ and the International Covenant on Economic, Social and Cultural Rights, ${ }^{29}$ as supplemented by the Convention Against Torture and other Cruel, Inhuman or Degrading Treatment or Punishment $^{30}$ and other international human rights instruments.

Within the European Union these principles have been incorporated into the Charter of Fundamental Rights of the European Union, ${ }^{31}$ the Tampere European Council Presidency Conclusions, ${ }^{32}$ and the draft Treaty Establishing a Constitution for Europe. ${ }^{33}$ Outside the framework of Community law, foundational principles were incorporated into the "Helsinki Process" that began with the Helsinki Summit Final Act of the Conference on Security and Co-operation in Europe (now the Organization for Security and Co-operation in Europe) of August 1, 1975. In its declaration of principles, the participating States "recognize the universal significance of human rights and fundamental freedoms." The 1990 Charter of Paris for a New Europe affirms that "Human rights and fundamental freedoms are the birthright of all human beings, are inalienable and are guaranteed by law." ${ }^{34}$ Within the forty-five-member Council of Europe system, the European Human Rights Convention ${ }^{35}$ is enforced by the European Court of Human Rights in Strasbourg. In addition, the European Social Charter ${ }^{36}$ contains a statement of important principles concerning access to employment and social programs.
European values with respect to human rights were forged in the conflict between traditional notions of state sovereignty and the need to deal with serious human rights abuses committed during the Second World War. Although Humanitarian Law as reflected in the Hague and Geneva Conventions codified international rules with respect to the conduct of war, the lack of an effective enforcement mechanism led to a sense of impunity among military and political leadership. In the spirit of legal positivism, many accused of war crimes cited domestic legal authority as justification for their crimes. With the demise of such morally based legal theories as natural law, a new foundation needed to be found which could place limits on state sovereignty. The first step towards the development of the concept of universal jurisdiction was made by the October 30, 1943, Moscow Declaration and the Charter of the International Military Tribunal of October 6, 1945, ${ }^{37}$ that gave the tribunal jurisdiction over crimes against peace, war crimes, and crimes against humanity. In subsequent years, principles of universal jurisdiction have been developed and now include enforcement by the International Criminal Court. In the early post-war period, the Council of Europe began work on a European Human Rights Convention to address issues raised by this legacy.

In light of the European experience, human rights responsibilities are taken very seriously within the various European systems. The development of the Common European Asylum System is no exception. However, it is being driven by an agenda that distinguishes between the Geneva Convention and subsidiary protection in significant ways. Those who approach the issue from the point of view of consistency within the body of international human rights law see no justification for such a distinction. The European Commission, however, does. What accounts for this difference of approach?

There are several possible answers to this question. One is that it responds to enforcement priorities by some governments of Member States. The Commission's approach seeks to balance protected human rights with an attempt to deal with a perceived abuse of the asylum determination system by those considered to be economic migrants. In order to achieve this goal, the system should contain as few "pull factors" as possible under established legal obligations. This focus on program integrity, enforcement, and the importance of following immigration rules and procedures (i.e., coming in through the front door, not the back door) reflect political values that are popular in a number of EU countries. An example of this can be found in the Committee of the Regions report on the Qualification Directive that supports the distinction between Convention refugees and those with subsidiary protection with respect 
to access to labour markets. Given that this 222-member body is made up of regional representatives, it reflects grassroots sensitivity to the impact of irregular entry into the EU on local employment, provision of social services, and integration issues. The conflicting approaches taken between the Committee of the Regions and the Economic and Social Committee demonstrate a contrast between a principled human rights approach taken by the latter with a politically sensitive one adopted by the former. The Committee of the Regions reflects the approach taken by the European Commission and supports the view that a common asylum system is best achieved through minimum standards that are not in conflict with binding international human rights obligations. If local economic and political conditions are such that a Member State wishes to be more generous, it is free to do so and to incur any risks that this added "pull factor" may produce.

A second explanation can be found in the nature of the European Commission itself and its roots in the functionalism that has accompanied the rise of contemporary bureaucracy. The classic expression of the dominant role assigned to central state authority can be found in the tradition of legal positivism. Law is understood from the point of view of the command of the sovereign that, by operation of principles of recognition, is accepted as binding and, to ensure effectiveness, is backed by threat of coercive measures. This approach is sometimes referred to as "normativism" because state "command" makes law normative. From John Austin in the nineteenth century to such contemporary writers as H.L.A. Hart, legal positivism has had a significant influence in Western jurisprudence. Normativism is based on the notion of law as promulgated by statute and as interpreted by courts. Although the nature of international law is different, the term can also be used to describe State obligations that are binding under international human rights law through Conventions, customary law, and jus cogens.

Normativism worked well when the role of central government was limited in scope to foreign relations and public policy issues that were amenable to debate in Parliament or the National Assembly. However, the rapid growth of industrialization in the late nineteenth century drew many from rural areas into overcrowded, unsanitary, and substandard urban housing. Long working hours, child labour, and unsafe working conditions were the order of the day. Social reformers gave voice to those who lobbied for the introduction of regulatory schemes to further social policy objectives related to quality of life. The dominance of capital over labour that had prevailed under the laissez-faire principles of Adam Smith and nineteenth-century liberalism needed to be tempered by the introduction of admin- istrative principles that could address issues of distributive justice and quality of life issues, as can be seen in the Roosevelt's "New Deal" of the 1930s. From this perspective, the role of the state is not to command in the name of dominant social classes, but rather to create, coordinate, and facilitate programs that allow the latent humanity of society to take institutional form. This marks a shift from the normativism that views political institutions as being the custodian of social values to one that looks to society itself as identifier of normative values through collective interaction.

With the rapid development of technology and communications, the need for specialized support in the area of regulation became evident. Administrative institutions that began as part of an agenda to promote quality of life developed into ones that designed and implemented complex regulatory schemes in virtually all areas of life. To a certain extent, one could say that the growth of administrative agencies in the twentieth century has created a fourth branch of government - the civil service. Rather than being limited to implementing instructions received from the legislature, civil servants have become social regulators in their own right, but nevertheless subject to political direction. Functionalism developed out of a history of attempts to develop the law in terms of social policy objectives, collective engagement, rationality, and fundamental human values. Rather than limiting the law to the broad strokes of statute, it developed a complex system of interdependent regulations that viewed the role of law in society from a holistic and mechanistic point of view. The civil service, administrative agencies, and tribunals are required to make it operational. Functionalism requires the co-operation of experts within the bureaucracy and specialized agencies with the political decision makers who set policy direction.

This is precisely what is evident in the work of the European Commission. It does not approach the question of a Common European Asylum System from the point of view of the normativism that is inherent in the total body of international human rights law and binding obligations, both on a U.N. and a European level, after asking what the fundamental underlying principles are, how they interconnect, and how best to incorporate and institutionalize them. Civil society goes beyond the letter of treaty law and asks questions about its spirit. The Commission has adopted a functional approach that attempts to coordinate asylum policy with larger issues of interdiction, border control, migration policy, integration, and foreign policy. For this reason, the impact of asylum policies on labour markets is a relevant factor for the Commission, but not to those who view this as irrelevant when considered from the perspec- 
tive of international human rights law. To put it another way, the Commission's proposals reflect bureaucratic values that attempt to create a coherent and principled policy for Europe that integrates all aspects of migration and asylum into Community law. Civil society and the Economic and Social Committee of the European Parliament view the matter from the point of view of normative human rights standards that must be respected quite independently of migration issues.

Given that the functionalism of the European Commission suits the political agenda of governments in Member States that promotes restrictive immigration and asylum programs, the Commission proposals are not likely to be made more generous at the level of the Council of the European Union as it sits in its Justice and Home Affairs configuration. As a decision-making body that represents the political instructions of home governments through ministerial-level delegates, it will likely support the use of minimum standards for a Common European Asylum System, although perhaps for political rather than technocratic reasons. The voices of advocates of international human rights normativism that have been falling on deaf ears will not likely affect the outcome of the Tampere I phase. But, what of Tampere II?

The goal of creating an area of freedom, security, and justice in Europe is being met through balancing of competing agendas. On the one hand, human rights obligations are fully accounted for in the directives and regulations. An important advance has been made with respect to a consistent interpretation of "particular social group" and agents of persecution under the Geneva Convention. On the other, citizens from Member States are excluded from the common system (although individual Member States can opt to include them). Subsidiary protection remains a secondclass status that many asylum seekers find themselves in, notwithstanding the "priority rule." Although the Strasbourg European Court of Human Rights has interpreted Article 3 of the European Human Rights Convention as expressive of the principle of non-refoulement, it could not impose positive status that would allow those who could not be removed to enjoy the treatment of a national. Each Member State has developed its own approach to this issue. Although the Common European Asylum System has helped by developing common minimum standards, they fall far short of those enjoyed by Convention refugees.

The approach taken by the European Commission and Council is essentially technocratic, functional, and systemic. Human rights obligations are seen as necessary building blocks that that must be arranged in conjunction with those relating to forced migration, international protection and development, foreign relations, immigration, domestic security, and social policy. In order to make the system work with maximum efficiency, human rights must be restricted to obligations that are binding through international law, domestic courts, or the European Court of Human Rights. The interest is in the letter of the law, not extrapolating its spirit to be applied to changing circumstances by reference to international human rights law principles. For this reason, the European Common Asylum System has adopted as its lowest common denominator obligations that must be accounted for and respected, given that there is no choice in the matter because of binding legal obligations. In response to criticism about this, the Commission points out that Member States are free to develop domestic asylum policy that goes beyond mandatory principles. But, given that the purpose of the system is to discourage asylum shopping, this answer would not likely be satisfactory to a country that wishes to set a higher standard for treatment of asylum seekers, but has concerns about the availability of resources to respond to an increase in numbers of claimants.

One of the challenges for the Common European Asylum System at the Tampere II stage lies in moving from minimum standards incorporated into domestic asylum determination proceedings to a common determination system and status that replaces subsidiary protection with a complementary form based on the protection needs of the person rather than on a functional analysis of economic and forced migration issues with a view to developing integrated and coherent European policies. Perhaps the recent Canadian experience in creating such a system could be helpful for the European Commission to consider. However, Canada has limited this form of protection to the Geneva Convention and to the equivalent of Article 3 of the European Human Rights Convention. The Qualification Directive includes broader categories of forced migration.

A significant issue that the EU must face relates to restrictions placed on access to protection of the Geneva Convention. First, citizens of the European Union have no right to claim asylum in another EU country. On May 1, 2004, ten countries representing seventy-five million people will join the EU. Given the mobility rights available to EU citizens, one could argue that asylum is no longer necessary. This fact does not abrogate international obligations undertaken by States Parties to the Geneva Convention. In response to concerns about state resources being overburdened through internal EU migration after May 1, the United Kingdom has announced a residency period of two years in order to be entitled to apply for social assistance. Although work permits are not needed for EU citizens, the United Kingdom will require worker registration for those from the new states. The result of this regime is 
that someone who may have a well-founded fear of persecution in one EU country cannot go to another Member State and claim asylum. Due to issues of training, language, or other personal circumstances, employment may not be possible. A prolonged ban on the receipt of public benefits would put the person in a situation of not having access to either Geneva Convention entitlements or the support necessary to live on. This is problematic from the point of view of respect for obligations undertaken by ratifying or acceding to the Convention. Second, the use of safe-country-oforigin provisions for purposes of admissibility to claim asylum is also very problematic. No country can be presumed to never be capable of creating the circumstances that may lead a person to flee for reasons described in the Geneva Convention. Although each claim must be heard individually, use such a list may be warranted to direct applications into an expedited stream. This is also true of the proposed concept of safe neighbouring countries who are States Parties to the ECHR.

Another challenge facing the implementation of the Common European Asylum System is that not all the building blocks are in place. Significant issues remain to be settled before the May 1, 2004, deadline mandated in the Treaty of Amsterdam. Bruno Waterfield has identified three concerns about this. ${ }^{38}$ First, failure to meet the deadline would have diplomatic consequences by sending the message that the EU cannot be counted on to deliver when required. Second, EU enlargement from fifteen to twentyfive countries could make finding agreement on such politically charged issues as asylum much more difficult. Third, legal questions would arise concerning the ability of the Council to act after an explicit treaty deadline has passed. Suffice it to say, the situation will change considerably after May 1, 2004.

Notwithstanding this, the debate between human rights normativism, European Commission functionalism, and political preoccupation with program integrity will no doubt continue into the Tampere II phase of the Common European Asylum System. Individual rights protected by State obligations will be respected. However, collective values relating to security, fairness to those who seek to enter by the front door, and equitable distribution of limited resources will form the basis of debate in order to set the boundaries for the tent - the European area of freedom, security, and justice. Whether there should be two tents offering different levels of hospitality depending on the legal classification of the risk encountered by those seeking shelter remains to be determined. However, the current state of the Tampere process suggests that the EU will not move from a system of subsidiary protection to one of complementary protection in the near future and will con- tinue to promote programs of interdiction and safe-thirdcountry or safe-country-of-origin regimes to restrict access to first-tier Geneva Convention status in Europe. Efforts will be made to streamline the system to promote rapid determination of claims and speedy removal of unsuccessful asylum seekers. External processing will be studied in the context of protected entry procedures and resettlement. This is a welcome development provided that it complements the European asylum system and does not create external processing centres for European asylum claims as proposed by the United Kingdom.

Perhaps this debate would be best conducted in conjunction with the international community by addressing the question of whether the status accorded to Convention refugees should also be available to those at risk of torture or cruel, inhuman, or degrading treatment or punishment under other international Conventions. The next question is whether this should also be true for those displaced by armed conflict or human rights abuses who do not meet the preceding definition. Given the historical context in which the Geneva Convention was drafted and the subsequent developments of international human rights law through custom, jus cogens, and by Convention, this may be an appropriate time for the international community to revisit the question of whether protection from a human rights point of view should be limited to non-refoulement outside of the application of the Geneva Convention or whether all international protection should now include the economic and social rights available to Convention refugees. In light of the UNHCR's Agenda for Protection and Convention Plus initiative, it may be an appropriate time to revisit the question of whether it is time to harmonize the status of all in need of protection under international human rights instruments. The second significant issue in Europe relates to responsibility sharing, safe-third-country lists, and safe countries of origin. In an era of globalization, should protection under the Geneva Convention shift from a question of individual State responsibility to one of regional protection? Should the European debate become an international discussion?

\section{Notes}

1. Official Journal C 325 of 24 December 2002 (as amended by the Treaty of Amsterdam).

2. Consolidated Version of the Treaty Establishing the European Community, Official Journal C 325 of 24 December 2002.

3. Official Journal C340 of 10 November 1997.

4. Official Journal C 325 of 24 December 2002 (as amended by the Treaty of Amsterdam).

5. Official Journal L 239, 22/09/2000 p. 0019-0062.

6. Official Journal C 274 of 19 September 1996. 
7. (EC) No. 343/203 of 18 February 2003.

8. Official Journal L 316 of 15 December 2000 p. 1.

9. Official Journal L 252 of 6 October 2000, p. 12.

10. 2001/55/EC.

11. Official Journal L 31/18 of 6 February 2003.

12. COM (2000) 578 final, Official Journal C62 E of 27 February 2001, p. 231.

13. Official Journal C 29 of 26 November 2002, p. 0143-0171.

14. Irish Presidency of the European Union, Informal meeting of the Justice and Home Affairs Ministers, Dublin, Ireland 22/23 January 2004, Orientation discussion on the amended proposal for a Council Directive on minimum standards on procedures in the Member States for granting and withdrawing refugee status at <http://www.statewatch.org/news/2004/jan/ European-Returns-policy.pdf $>$.

15. European Council on Refugees and Exiles, ECRE's Recommendations to the Justice and Home Affairs Council on the "Safe Third Country" concept at its meeting on 22-23 January 2004, AD1/01/2004/.EXT/MTGB, 15 January 2004.

16. COM/2001/0510 final - CNS 2001/0207, Official Journal C 051 E of 26 February 2002, p. 0325-0334.

17. COR/2002/93.

18. ESC/2002/683.

19. See the memorandum by the United Nations High Commissioner for Refugees to the European Union Committee (SubCommittee E) of the House of Lords, Session 2001-02, $28^{\text {th }}$ Report of 16 July 2002 (minutes of evidence dated 24 April 2002), particularly the commentary on Article 2(a).

20. See the Memorandum by Professor Guy S. Goodwin-Gill to the European Union Committee (Sub-Committee E) of the House of Lords, Session 2001-02, $28^{\text {th }}$ Report of 16 July 2002 at paragraph 4-8 (minutes of evidence dated 10 April 2002).

21. For details, see his supplementary memorandum to SubCommittee $\mathrm{E}$ of the European Union Committee of the House of Lords, Session 2001-02, $28^{\text {th }}$ Report, 16 Jul 2002.

22. See, for example, Matter of Acosta, 19 I\&N Dec. 211, 222 (BIA 1985) of the U.S. Board of Immigration Appeals; AttorneyGeneral of Canadav. Ward (1993) 103 D.L.R. (4th) 1, and Chan v. Minister of Employment and Immigration 128 D.L.R. (4th) 213,247 , both in the Supreme Court of Canada, and in the British House of Lords, see Islam (A.P.) v. Secretary of State for the Home Department; Regina v. Immigration Appeal Tribunal and Another Ex Parte Shah (A.P.) (Conjoined Appeals), [1999] 2 AC 629 of 25 March 1999.

23. Council Directive 2003/86/EC of 22 September 2003.

24. 2000/C 116 E/15) COM (1999) 638 final - 1999/0258(CNS).

25. See Communication from the Commission to the Council and the European Parliament integrating migration issues in the European Union's relations with third countries, COM (2002) 703 final of 3 December 2002.

26. See, for example, Jane McAdam, The European Union proposal on subsidiary protection: an analysis and assessment, Working Paper No. 74, New Issues in Refugee Research, UNHCR (December 2002), online: <www.unhcr.ch>. See also European Council on Refugees and Exiles, Comments on the proposal for a Council Directive on minimum standards for the qualification and status of third country nationals and stateless persons as refugees or as persons who otherwise need international protection (March 2002), online: <http://www.ecre.org/statements/ statuscomms.shtml >. Professor Goodwin-Gill also makes this point in his memorandum to the House of Lords European Union Committee, previously cited in note 20.

27. U.N.G.A. Res. 217A (III), December 10, 1948.

28. U.N.G.A. Res. 2200A (XXI), December 16, 1966 (entered into force on March 23, 1976).

29. U.N.G.A. Res. 2200A (XXI), December 16, 1966 (entered into force on January 3, 1976).

30. U.N.G.A. Res. 39/46, [annex, 39 U.N. GAOR Supp. (No. 51) at 197, U.N. Doc. A/39/51 (1984)], entered into force June 26, 1987.

31. 2000/C 364/01. The Charter of Fundamental Rights of the European Union was declared at the Nice European Council on 7 December 2000.

32. Available at $<\mathrm{http}: / / w w w . e u r o p a r l . e u . i n t / s u m m i t s / t a m \_e n$. htm\#union $>$.

33. CONV 850/03 of 18 Jul 2003.

34. Both the Helsinki Final Act and the Charter of Paris for a New Europe are available on the OSCE web site at: <http://www. osce.org/docs/english/summite.htm>.

35. (ETS NO. 5), 213 U.N.T.S. 222, entered into force 3 Sept 1953.

36. ETS No. 035 (Turin, October 18, 1961), as revised in ETS No. 163 (Strasbourg, May 3, 1996). A complaint mechanism was established through a protocol - ETS 158 (Strasbourg, September 9, 1995).

37. Agreement for the Prosecution and Punishment of the Major War Criminals of the European Axis (London Agreement), August 8, 1945, 58 Stat. 1544, E.A.S. No. 472, 82 U.N.T.S. 280.

38. Bruno Waterfield, Asylum Policy Faces "Huge Challenge," 17 February 2004. See full text online: <http://www.eupolitix. com/EN/News/200402/cd271116-cfee-4a22-80aa-f2d2b833f f3f.htm>.

Harold Shepherd is a Toronto refugee lawyer with an LL.M. in administrative law from Osgoode Hall Law School. After private practice he worked as the executive director of a refugee resettlement agency, then joined Citizenship and Immigration Canada to represent the Minister at refugee hearings before the Immigration and Refugee Board. He now works for the Canada Border Services Agency as a pre-removal risk assessment officer, determining applications to the Minister for refugee protection. The views expressed in this article are his own and do not reflect policy of the Government of Canada. 